\title{
Agriculture After Cancún
}

Trinity Economic Paper No. 17, 2003

\begin{abstract}
Alan Matthews*
(This revised version of the paper completed 11 March 2004 replaces the earlier version dated 5 December 2003).

*Alan Matthews is Jean Monnet Professor of European Agricultural Policy Trinity College Dublin. Correspondence to Alan.Matthews@tcd.ie
\end{abstract}




\section{Introduction}

WTO Members met for the Fifth Ministerial Conference at Cancún in September 2003 to undertake a mid-term review of the Doha round of trade negotiations. Agriculture is a key element of these negotiations as mandated in the Declaration launching the Doha Round:

"Building on the work carried out to date and without prejudging the outcome of the negotiations we commit ourselves to comprehensive negotiations aimed at: substantial improvements in market access; reductions of, with a view to phasing out, all forms of export subsidies; and substantial reductions in tradedistorting domestic support. We agree that special and differential treatment for developing countries shall be an integral part of all elements of the negotiations and shall be embodied in the Schedules of concessions and commitments and as appropriate in the rules and disciplines to be negotiated, so as to be operationally effective and to enable developing countries to effectively take account of their development needs, including food security and rural development. We take note of the non-trade concerns reflected in the negotiating proposals submitted by Members and confirm that non-trade concerns will be taken into account in the negotiations as provided for in the Agreement on Agriculture." (WTO, 2001).

The failure of the Cancún Ministerial to reach agreement on a framework text on negotiating modalities for the market access agenda and on the extent of new rulemaking left the agricultural negotiations, as with the other areas under negotiation, in suspension. A meeting of the WTO General Council on 15 December 2003 was unable to provide the necessary momentum to move towards a successful and timely conclusion of the negotiations. However, although there is little sign at the beginning of 2004 that countries are yet ready to re-engage in meaningful negotiations, it is too early to write off the Round as dead.

Agriculture is one of the make-or-break issues in the Doha Round. Thus it is timely to review what progress was made, if any, in the discussions on agriculture in the run-up to Cancún and whether the shape of a final agreement can yet be discerned. This chapter addresses this question through an analysis of the successive drafts of the framework text on the modalities of the agricultural negotiations and a comparison of the positions of the major players in these negotiations. ${ }^{1}$ Particular attention is paid to the position of the developing countries and the way their concerns have been addressed in successive drafts. The paper is upbeat about the prospects of reaching an agriculture agreement. It argues that the main constraint to a successful resumption and conclusion of the Doha Round lies in broader political calculations in areas other than agriculture, but that progress in agriculture could greatly assist in improving the overall prospects for success.

\footnotetext{
${ }^{1}$ A similar exercise undertaken by the International Centre for Trade and Sustainable Development only came to my attention after the completion of this chapter (ICSTD, 2003). See also the agricultural backgrounder regularly prepared by the WTO Secretariat and updated 1 March 2004 (WTO, 2004).
} 


\section{The Road to Cancún}

The first draft text on modalities was circulated to WTO Members by Stuart Harbinson, Chairman of the Special Session on Agriculture, on 12 February 2003. A mini-ministerial meeting in Tokyo later that month was the first opportunity for some of the WTO membership to comment on the paper. The proposal failed to get much support and, indeed, no country strongly supported the first draft. Members could not even agree on a term to describe the draft (whether as a starting point, reference or basis for the negotiations), eventually agreeing to call it a 'catalyst'. Despite these disagreements, however, Harbinson's second draft in the following month made few significant changes. ${ }^{2}$

A second mini-ministerial took place in Montreal on 28-30 July. Despite some limited signs of flexibility (for example, the EU increased its offer to cut trade-distorting support from $55 \%$ to $60 \%$, while expressing its willingness to eliminate export subsidies and expand tariff rate quotas for an agreed list of products) the meeting failed to give a political momentum to the negotiations. Following that meeting, the US and the EU were asked to work together to break the deadlock.

In August 2003, the EU and the US issued a joint framework suggesting some areas of agreement on how they thought progress could be made. Among other things, this text proposed a blended formula for tariff reductions, a special safeguard for developing countries to protect sensitive products and improved duty-free access for developing country exports. Many of the proposals from this paper were included in the framework text on agriculture contained in Annex A of the Draft Ministerial Text prepared by the WTO Secretariat and published on 31 August as the basis for discussion at the Cancún meeting (called the Castillo draft after the Chairman of the General Council) (WTO, 2003a).

Developing countries felt that this text leant excessively in the direction of developed country interests and it sparked a series of counter-proposals. A group of (initially) 21 developing countries, including Brazil, China, India and South Africa (now usually referred to as the G20 as its membership varied both during and after the Cancún meeting), put forward an alternative text ${ }^{3}$, followed by the African and least developed countries, which proposed another (WTO, 2003b). Four African cottonproducing countries pursued a Sectoral Initiative on Cotton demanding the removal of all cotton subsidies and financial compensation while the subsidies still existed.

A revised framework text on agriculture was presented to the Conference by the Secretariat on 13 September (called the Derbez draft after the Mexican Foreign Minister who chaired the conference) (WTO, 2003c). Although the negotiations on this text broke down the following day because of incompatible positions on the Singapore issues ${ }^{4}$, there was some optimism that a deal could be reached on

\footnotetext{
${ }^{2}$ This is not surprising. A statistical analysis by the Danish Research Institute of Food Economics (2003) which measured the distance between the negotiating proposals of each country showed that the Harbinson draft, if it were considered as the negotiating proposal of a separate 'country', was located in the middle of all other major proposals.

${ }^{3}$ The G21 alternative text on agriculture can be found at www.icstd.org.

4 The Singapore issues cover trade and investment, trade and competition policy, transparency in government procurement and measures to facilitate trade such as the simplification of customs
} 
agriculture on the basis of this draft. The manner in which it addressed the concerns of the major participating groups is discussed in the following section of the paper.

The Cancún conference was notable for the capacity of developing countries to organise around common positions. While the Uruguay Round negotiations on agriculture were largely a US-EU affair, and were concluded once these countries reached the Blair House agreement, the Doha Round negotiations are more a NorthSouth issue although with sub-plots within each of these groupings. Already at the Doha Conference a loose alignment of developing countries calling themselves 'Friends of the Development Box' had been formed to promote acceptance of ideas for greater special and differential treatment for developing countries in the agriculture agreement. The G20 group was notable for bringing together countries which traditionally have held very divergent positions in the agricultural negotiations, particularly on the importance to be attached to the Development Box. While the G20 grouped the developing country heavyweights, the least developed countries, African, Caribbean and Pacific (ACP) and African Union countries came together in a group which was designated (by others if not by themselves, since the group contains only 61 WTO members, 2003) as the G90, led by Mauritius. This group, in addition to supporting the Development Box proposals, sought measures to address tariff peaks and escalation, the binding of preferential access to developed country markets, and a compensatory mechanism to compensate for the erosion of trade preferences due to tariff liberalisation. A final group of eventually 33 countries (dubbed the G33), led by Indonesia and the Philippines, formed the Alliance for Strategic Products and a Special Safeguard Mechanism, which emphasised the particular importance of strengthening measures to protect vulnerable farmers.

Membership of these groups overlapped, and the fact that leading countries in each alliance are members of the Cairns Group of agricultural exporting countries is also significant. The Cairns Group, which had been dominated by Australia following a hard-line free trade stance focusing on improved market access and the removal of subsidies, played a much more subdued role in Cancún as its developing country members followed a more development-oriented path. CAFOD remarks on the fact that agriculture was the focus of all these developing country groupings, highlighting its central importance for them and the essential distraction which the Singapore issues represented (CAFOD, 2003).

The cotton initiative proposed by four West and Central African LDCs - Benin, Burkina Faso, Chad and Mali - became the symbolic issue at Cancún, just as access to medicines at the Doha Conference. The African countries requested an 'early harvest' decision in Cancún to phase out all cotton subsidies and domestic support measures by 2005, along with the payment of compensation to LDCs during the transition period. The US and the EU were opposed to a decision of this kind, which they viewed as setting a precedent for commitments on specific products, challenging the aggregate approach adopted for Amber Box trade-distorting subsidies in the AoA.

procedures They are referred to as the Singapore issues because the Ministerial Declaration following the WTO Council meeting in Singapore in 1996 agreed to establish working groups to analyse them.

5 The EU position has since become more supportive of the African countries' position, see Commission (2003). 
A further feature of the Cancún conference was the role played by civil society organisations. Development NGOs turned up in strength and acted as a counterweight to the farm lobby representatives in influencing national delegations. The EU Agricultural Commissioner went so far as to partly blame their influence on developing country delegations for the breakdown of the talks. While the comment was seen as somewhat patronising with respect to developing country governments $(C A F O D, 2003)$, it provides a further illustration of the changed dynamics of the conference negotiations.

\section{Analysis of the key issues}

This section of the paper traces how negotiating positions have been reflected in successive draft texts of the modalities, beginning with the Harbinson draft through the Castillo text at the outset of the Cancún conference and the Derbez text at the end of that conference. Areas of agreement as well as disagreement are highlighted in order to form a view on the degree of convergence which has been achieved in the negotiations to date.

\section{Market access}

The US proposal on market access was to use a harmonising formula (the Swiss formula $^{6}$ ) to reduce agricultural tariffs, ensuring that no individual tariff exceeds $25 \%$ after a five-year phase in period. Tariffs should be simplified to either ad valorem or specific, but not mixed. The EU, on the other hand, proposed to continue the Uruguay Round (UR) linear formula, reducing agricultural tariffs by $36 \%$ on average, with a cut of at least $15 \%$ per dutiable item.

The Harbinson draft proposed a banded approach. Tariffs greater than $90 \%$ would be reduced by $60 \%$ on average, with a minimum cut of $45 \%$ per tariff line. Tariffs between 90 and $15 \%$ would be reduced by $50 / 30 \%$, while tariffs lower than $15 \%$ would be reduced by $40 / 25 \%$. Reductions would take place in equal instalments over five years. Developing countries would be given a ten year implementation period and lighter reduction commitments. Least developed countries would not be required to undertake reduction commitments but might be encouraged to do so on a voluntary basis, taking into account their development needs. Newly acceded countries (such as China), who often offered more ambitious tariff concessions than those required under the UR formula, would have the flexibility to defer the implementation period for new commitments by two years. The Harbinson formula was opposed both by the supporters of a Swiss formula approach (which would bring all tariffs down to a specific maximum level) and by those (such as the EU) which wanted to continue the flexibility to have smaller reductions for certain sensitive products.

The joint EU-US framework proposal proposed a blended approach instead. Some proportion of tariff lines would be subject to a Swiss formula coefficient; some proportion would be subject to the UR formula of an average tariff cut subject to a minimum; and some proportion of tariff lines would be duty-free. Moreover, a maximum tariff level would be agreed; countries which wished to retain tariffs above

\footnotetext{
${ }^{6}$ The Swiss formula is $T_{n}=\left(a_{\max } * T_{0}\right) /\left(a_{\max }+T_{0}\right)$ where $T_{0}$ is the original tariff, $T_{n}$ is the new tariff and $\mathrm{a}_{\max }$ is the upper bound on all resulting tariffs. With $\mathrm{a}_{\max }=50$, an initial tariff of 40 per cent would be reduced to 22 per cent.
} 
this level would be required to offer effective additional market access through a request/offer process, including increases in tariff rate quotas.

The G20 group accepted this blended approach although - for the UR element of the formula - they proposed a simple uniform tariff cut (instead of an average reduction subject to a minimum). However, for developing countries, they proposed the continuation of the UR formula across-the-board. They also called for an overall target for average tariff reductions by developed countries. Similar demands were included in the G90 proposal.

The Castillo draft retained the blended formula approach based on the EU-US framework proposal, while adding the proviso that the resulting simple average tariff reduction for all agricultural products should be no less than a specified minimum as called for by the G20. It proposed to treat maximum tariffs as in the EU-US framework proposal, although the Derbez text offered a slight loophole that additional flexibility would be possible for a limited number of products on the basis of nontrade concerns. From the G20 perspective, an objectionable element of this text was that it retained the use of the Swiss formula also for developing countries, implying a maximum tariff level for at least some products.

Harbinson recognised the need for special and differential treatment for developing countries by proposing lower tariff reductions and longer implementation periods. However, both the Castillo and Derbez texts proposed that setting maximum tariffs also for developing countries should remain under negotiation, a proposal rejected by the developing countries. Reflecting the demand for a Development Box, Harbinson introduced the concept of 'Special Products' (SPs) which would be defined with respect to food security, rural development and/or livelihood security concerns. Harbinson suggested that the tariff reductions to be sought on SPs should be limited to an average of $10 \%$ (with a minimum reduction of $5 \%$ ). The Castillo draft proposed a less attractive formulation from a developing country perspective, namely, a lower minimum reduction for SPs within the proportion of tariff lines which would be subject to the UR linear formula. Presumably, this would require compensating higher reductions on other tariff lines in order to achieve the overall targeted average reduction. The Castillo draft also proposed exempting SPs from any obligation to increase Tariff Rate Quotas (TRQs). The Derbez text added that, where existing tariff bindings were very low, no further reductions would be sought. Development Box proponents see these as very weak provisions to secure the protection they believe to be necessary for these particularly sensitive products.

An important element of the market access proposals in the Harbinson draft proposals was a clear formula to address tariff escalation issues. Where the tariff on a processed products was higher than the tariff for the product in its primary form, the rate of tariff reduction for the processed product would be equivalent to that for the product in its primary form multiplied by, at a minimum, a factor of 1.3. The EU-US framework text did not address this issue, and in the Castillo draft, it was reduced to 'best endeavour' language, stating that "the issue of tariff escalation will be effectively addressed." The G20 draft proposed retaining the Harbinson formula, and it was reinstated in the Derbez text. 
The Harbinson draft proposed the elimination of the current special safeguard mechanism (SSG) which allows countries to levy an additional, time-limited import surcharge to protect domestic producers from a sudden surge in imports of certain products. This mechanism is only available to products which underwent tariffication in the UR and where countries had reserved the right to use it in their schedules. In the EU-US framework text, the use of the SSG was left as a matter for further negotiation and this language was retained in the Castillo and Derbez texts. The G20 draft calls for the conditions and timetable for its elimination to be negotiated.

The Harbinson modalities also included provision for a new Special Safeguard Mechanism (SSM) to be added to the modalities to enable developing countries to effectively take account of their development needs. The SSM is strongly supported by both the G20, the G90 and the G33 "subject to conditions and for products to be determined". The EU-US framework draft also accepted a SSM but linked it to the notion of "import-sensitive products" which would also benefit from lower tariff reduction commitments. Both the Castillo and Derbez texts contained a proposal to establish a SSM along the lines of the G20 proposal. Other developing countries in the G33, however, want the SSM to be available for all products, as well as ensuring that SPs would also have access to the SSM.

On TRQs, the Harbinson text proposed that quota amounts would be increased up to $10 \%$ of current domestic consumption of each product, as well as calling for simplification and greater transparency in the administration of tariff rate quotas. It did not propose a reduction of in-quota tariffs, except for tropical products or products which might substitute for crops which were illegal or harmful to human health, or where fill rates over a recent period had been particularly low. The EU-US proposal did not address this issue, although it implied that TRQs would be increased in cases where countries made use of the flexibilities under the tariff reduction formula to maintain particularly high tariffs or to implement minimum reductions for importsensitive products. Taking its cue from this draft, the Castillo and Derbez texts proposed a reduction of in-quota tariffs while leaving the terms and conditions of further TRQ expansion under negotiation. The G20 text supports the Harbinson draft in calling for an expansion of TRQs, while the G90 text contents itself with a call for simplification and greater transparency of TRQ regimes.

The erosion of trade preferences following from any reduction in agricultural tariffs in developed countries has emerged as an important issue for a number of developing countries. The Harbinson draft modalities called for the maintenance of the nominal margins of tariff preferences where technically feasible - this is obviously not possible in cases where duty-free access is already granted. It proposed a longer implementation period and a two year moratorium for "tariff reductions affecting long-standing preferences in respect of products which are of vital export importance for developing country beneficiaries.." How this would work in practice is not clear, as eligible products are defined as those which account for at least $20 \%$ of the total merchandise exports of any beneficiary. This would seem to open up a potentially large number of products for which this special exception would apply. The formulation is supported in both the Castillo and Derbez texts, as well as in the proposals from the G20. The G90, in addition, seek the development of a compensatory mechanism to address the erosion of preferences for countries adversely affected. 
The EU-US framework text addressed this issue by calling for duty-free access for a certain percentage of developing country imports to be provided "through a combination of Most Favoured Nation and preferential access". 7 This formulation was carried into the Castillo and Derbez texts, although using the 'best endeavour' language that all developed countries "will seek to provide" this minimum amount of duty-free access. The G20 text strengthens this to the mandatory "shall provide", with the implication that, where provided through preferential schemes, this access would be bound in the schedules of commitments entered by developed countries. The Harbinson draft modalities, in addition, had offered that developed countries either "should" or (much stronger) "shall" provide duty- and quota-free access to their markets for all agricultural imports from the least developed countries. This was weakened to 'best endeavour' language in the Castillo text that the objective of dutyand quota-free access for least developed countries "shall be expeditiously pursued". Both the G20 and the G90 sought the stronger Harbinson alternative and, in the Derbez text, the Harbinson dual formulation was restored.

\section{Export subsidies}

As was evident already in negotiating the Doha mandate in November 2001, the future of export subsidies is a hotly contested issue. The US, Cairns Group and developing countries have called for their elimination. The EU is the single largest user of export subsidies, accounting for around $85 \%$ of the total by value notified to the WTO Committee on Agriculture. It had originally proposed a $45 \%$ reduction in expenditure on average, provided that all forms of export subsidies, including export credits and the activities of state trading exporters, were treated equally.

The Harbinson draft proposed that export subsidies for products accounting for $50 \%$ of export subsidy expenditure would be phased out over five years, while the remainder would be phased out over nine years, with the greatest reductions occurring in the earlier years. Developing countries would be given 10 and 12 years respectively. In the EU-US framework text, the EU offered to eliminate export subsidies on certain products of particular interest to developing countries (to be determined) while subsidies for the remaining products would only be reduced.

The Harbinson text had also proposed to discipline export credits. Non-conforming export financing subsidies would be subject to reduction commitments, with exceptions for emergency situations in importing Members. The EU-US framework text proposed that parallel disciplines should be applied to export credits, state trading export enterprises and food aid programmes. It also added that, without prejudging the outcome of the negotiations, reductions of, with a view to phasing out, all forms of export subsidies including export credits would occur in a parallel manner.

The Castillo text combined these elements by affirming that reduction commitments shall be applied in a parallel manner to export subsidies, export credits, export state trading enterprises and food aid. It retained the commitment to phase out export subsidies for products of interest to developing countries, but added that, for the

\footnotetext{
${ }^{7}$ In its original negotiating proposal to the Special Session, the EU proposed zero duty access for $50 \%$ of total imports of agricultural products from developing countries, as well as unrestricted access for imports from the least developed countries.
} 
remaining products, "Members shall commit to reduce, with a view to phasing out, budgetary and quantity allowances for export subsidies". The G20 draft proposed adding a definite time horizon to this last commitment, turning it from a 'best endeavour' to a mandated commitment, but the Derbez draft retained the Castillo wording. However, the Castillo draft contained a commitment (para. 3.6) that "the question of the end date for phasing out all forms of export subsidies remains under negotiation". This was further strengthened in the Derbez draft to become "An end date for phasing out all forms of export subsidies remains under negotiation", thus changing the issue from 'if' to 'when' (CAFOD, 2003).

\section{Domestic support}

While high-support countries are broadly satisfied with the Green Box as defined in the URAA, intended to permit countries to continue support programmes to agriculture which are deemed to be not or minimally trade-distorting, agricultural exporters and developing countries have sought to limit Green Box payments, arguing that their sheer volume has a distorting effect on global trade. The Harbinson draft modalities did propose some minor tightening of the criteria for eligibility for the Green Box in Annex 2 of the URAA but did not propose a cap on Green Box spending or remove any income support payments from the Green Box. At the same time, it responded to the demands from the EU, Switzerland and others to allow payments for animal welfare programme to be classified as a Green Box measure.

The Castillo text simply noted that the Green Box criteria remain under negotiation. This was slightly strengthened in the Derbez draft to state that Green Box criteria shall be reviewed with a view to ensuring that Green Box measures have no, or at most minimal, trade-distorting effects or effects on production. The G20 text altered this to propose that the Green Box disciplines should be strengthened with a view to ensuring that Green Box measures have no, or at most minimal, trade-distorting effects or effects on production.

Developing country interest also focused on Article 6.2 measures to encourage agricultural and rural development which are exempted from reduction commitments under this paragraph. The Harbinson draft modalities proposed extending the range of exempted measures and attached a list of possible amendments for further consideration. Surprisingly, this issue was not explicitly included in either the Castillo or Derbez texts nor in the G20 draft.

With respect to trade-distorting (Amber Box) support, the Harbinson draft proposed that the Aggregate Measurement of Support (AMS) should be decreased by $60 \%$ in five years for developed countries, and $40 \%$ in ten years for developing country members. The EU-US draft did not contain numbers for the extent of the reduction in trade-distorting support, but it did state that the reductions would be "significantly larger than in the Uruguay Round" (namely, 20\% for developed countries). It also stated that Members with higher levels of trade-distorting subsidies would have to make greater efforts than others. The unspecified AMS reduction was carried into the Castillo draft, but a significant addition in the Derbez text was the commitment that product-specific AMS shall be capped at their respective average levels during a base period to be agreed. The G20 proposed, in addition, that the product-specific ceilings might be reduced in further negotiations and that, for heavily exported products, 
additional disciplines should be negotiated. The EU-US text also proposed a reduction in de minimis limits which was repeated in both the Castillo and Derbez drafts, although developing countries would be exempt from this reduction.

The Uruguay Round Agreement introduced the Blue Box category of productionlimited support. The Harbinson draft proposed to cap these payments at their 19912001 level and reduce them by 50\% over five years. Alternatively, it suggested that the Blue Box should be merged with the Amber Box. The US had initially proposed to scrap the Blue Box entirely, but the EU-US framework text proposed to cap Blue Box spending at $5 \%$ of the total value of agricultural production at the end of the implementation period. It also proposed to relax the criteria for Blue Box payments by no longer requiring production limiting or supply management programmes. Under this new design, the US could seek to exempt its countercyclical payments under the 2002 Farm Act from its reduction commitments. The EU-US text also proposed a reduction in de minimis limits, as well as introducing a new ceiling where the sum of Amber Box, Blue Box and de minimis payments would be significantly reduced below the combined sum of these payments in 2004.

This formulation was carried over into the Castillo draft (with the total value of agricultural production fixed at the level of the 2000-2002 period) with the cap to be achieved by a specified date and with the proviso that, following that date, such support would be subject to a further linear reduction for an additional period of years. The Derbez text added that there should be a specified cut in the first year of implementation in the total sum of support under the Amber Box, Blue Box and de minimis ceilings. The G20 draft sought stronger disciplines on Blue Box support, seeking to cap it at $2.5 \%$ of the value of production in the initial implementation phase and proposing that the subsequent linear cuts in Blue Box payments would continue "with a view to its phasing-out".

\section{Evaluation of the state of play of the negotiations}

Despite the failure at Cancún, the positive movement in the negotiations on agriculture to date should be noted. With respect to market access issues, the tariff reductions on offer in the Derbez text are potentially larger than those agreed in the Uruguay Round. ${ }^{8}$ There is the prospect that tariff peaks would be addressed. A clear formula is on offer to address tariff escalation. Moreover, the principle of special products and a special safeguard mechanism for developing countries has been accepted by the developed countries, there is the possibility of mandatory binding of duty- and quota-free access for the least developed countries and acceptance of minimum levels of duty-free access for products from developing countries.

Compared to the Uruguay Round Agreement, there has also been significant progress in the area of export subsidies. An offer to phase out export subsidies on a list of products of interest to developing countries has been made, as well as a commitment to significantly reduce remaining export subsidies in parallel with disciplines on other forms of export competition. The Derbez text also appears to move forward from the

\footnotetext{
${ }^{8}$ This partly depends on whether the reductions are compared in absolute or in proportionate terms. To achieve the same absolute reduction as the $36 \%$ reduction agreed in the UR would require a cut of $36 / 64$ or $56 \%$ in the remaining tariffs. Any percentage average reduction less than $56 \%$ would imply that the absolute cut in tariffs would be smaller than in the UR.
} 
Doha mandate in requiring members to negotiate a final date for the end of all export subsidies, although the EU would still have difficulty in agreeing to this (CAFOD, 2003).

Finally, much larger reductions in trade-distorting support, including Amber Box and de minimis payments, are now on offer than in the Uruguay Round. Furthermore, a cap will be placed on Blue Box payments. Special and differential treatment would apply to developing countries, including lower reduction commitments for Amber Box support, longer implementation periods and enhanced provisions under Article 6.2 .

Despite this evidence of convergence in positions, significant differences remain. In the market access negotiations, three conditions raised by the developed countries could still cause difficulties. First, the EU is adamant that, while developing countries should continue to receive special and preferential treatment, this should not imply a different set of rules, but different implementation periods and extent of commitments based on the same rules. The EU does not agree to the blended formula approach (including applying the Swiss formula to a certain percentage of tariff lines) for developed countries and the Uruguay Round approach alone for developing countries. A second potential stumbling block is the insistence of both the EU and the US, in their framework text, that the rules and disciplines for special and differential treatment should be adjusted for significant net-exporting developing countries. This idea of differentiation ('graduation') - which is also promoted by the EU and others across all areas of negotiation in the Doha Round - is very opposed by the developing countries. However, the EU has highlighted that much of the benefits of the Round lie in the potential for increased South-South trade which is currently restricted by high developing country tariffs. It is also proposing that the more advanced developing countries should commit to provide duty-free and quota-free access for the agricultural exports of the LDCs, partly as a way of compensating for the erosion of their preferential access to developed country markets. Third, the EU has made very little progress to date on its demands on non-trade concerns such as consumer protection, food safety, extension of Geographical Indications, the environment and animal welfare. The Harbinson text merely called for further consideration. The EUUS framework text simply noted that these were issues of interest that were not yet agreed, and this language has been carried into the Castillo and Derbez drafts as well.

From the developing country perspective, the blended formula approach to tariff reductions may not provide the sharp reductions in developed country tariffs they want to see. For example, a characteristic of the EU's bound tariffs is the great variance in individual rates. Large numbers of tariff lines have zero or relatively low MFN duties, but for a small number of tariff lines MFN duties are very high. By putting the relatively low tariffs into the grouping subject to the Swiss formula and a maximum tariff while dealing with the high tariff items through the linear Uruguay Round formula subject to a minimum reduction for sensitive commodities, the EU could avoid making significant reductions in its highest tariff rates (although the EUUS text did provide for expanded TRQ access where Members took advantage of the minimum rate reductions). Many developing countries, including India, also argue that the current proposals on Special Products would need to be strengthened considerably before they are acceptable. 
The export subsidy area still has the potential to cause difficulties, particularly for the EU. However, it is my view that all those involved in EU agricultural policy now accept that export subsidies are an indefensible form of trade policy instrument; the question is not whether they should be eliminated, but when. The key issue for the EU is the question of parallelism. If sufficiently watertight commitments can be given to equally discipline export credits, food aid and the activities of single desk exporters, the EU would find it very difficult to resist pressure to agree a date for their elimination, and the only issue would be the timeframe for this to happen.

In the area of domestic support, the contentious areas which remain are whether Blue Box payments should be further reduced and whether Green Box criteria should be further strengthened. Developing countries argue that the sheer scale of these payments distorts trade and have called for the elimination of the Blue Box and reductions in Green Box support. The EU insists that all forms of support are not equally trade distorting and that this distinction must be maintained. It is concerned that its recent efforts in the Mid-Term Review of the Agenda 2000 CAP reforms to shift spending from Blue Box to Green Box (decoupled) payments should not be undermined. It does not want to see the Blue Box ceiling further reduced or phasedout in the future, and it is concerned that the Green Box criteria should remain sufficiently flexible to allow continued support to EU farmers to enhance environmental, food quality or safety and animal welfare objectives. With sufficient movement on market access and export subsidies, it is unlikely that these differences on domestic support would prove a stumbling block to an ultimate agreement.

Through the smokescreens of individual countries' negotiating positions, the broad outlines of the deal are clear. Developed countries will commit to significant reductions in tariffs and trade-distorting domestic support payments and the elimination of export subsidies, in return for a commitment by the developing countries to accept some lowering of their bound tariffs, subject to a deal on Special Products where lesser commitments would apply, while least developed countries would be exempt from reduction commitments. The fact that, for most developing countries, bound tariffs are well in excess of applied tariffs so that this discipline will not have any immediate impact, will make it easier to accept. Various side-payments would need to be made to ensure the agreement of key players, e.g. addressing the EU's concern over GIs, developing countries' concerns over special safeguards and the concern of preference recipients over preference erosion. However, these would not alter the basic parameters of potentially a very far-reaching and worthwhile agreement, also from the point of view of developing countries.

\section{After Cancún}

\section{The regionalism option}

Following the Cancún talks breakdown, US Trade Representative Robert Zoellick famously attributed the breakdown to a divide between the "can do" and "won't do" countries. "The rhetoric of 'won't do' overwhelmed the concerted efforts of the 'can do."' he said. He subsequently developed this theme in a Financial Times article in which he suggested that the US would place more effort in trying to secure its trade objectives through bilateral or regional deals with the "can do" countries if the multilateral process remained bogged down (Financial Times 22 September 2003). 
The US is currently negotiating free trade area agreements with Morocco, Australia and the Central America Free Trade Agreement but these are hardly significant in global terms. As Lamy gleefully pointed out in a Washington speech in early November, "I am not going to lose any sleep about Bob Zoellick pursuing an FTA with Morocco, where the US starts from a tiny percentage of Morocco's total trade... And did you know how many FTAs the US has? Six, including counting NAFTA as two. The EU.. has got a fair few more than that..." (Lamy, 2003). A number of Latin American countries, including Columbia and Peru, have since left the G20 group in order to be able to pursue bilateral agreements with the US, but the big prize for the latter is the Free Trade Area of the Americas (FTAA) that would give it greater access to markets in the Western Hemisphere. However, the US, backed by Canada, has insisted that it will only negotiate concessions on agricultural subsidies (and antidumping rules) - both key concerns of Latin American countries - in the Doha Round and not in the FTAA (Financial Times 24 September 2003.) On the other hand, US demands that the talks should cover issues such as rules on services, investment, government procurement and intellectual property have been resisted by Brazil. Both sides appeared to set a fairly low threshold for success at their ministerial conference in Miami in mid-November (Financial Times 15 November 2003).

For the EU, with its extensive network of regional arrangements, using the threat of regionalism to try to make progress on its multilateral agenda is less convincing. However, it continues to extend this network (for example, most recently with Mexico) and has also been pursuing talks with Mercosur. Lamy has argued that, if the multilateral process fails, the EU would look again at pursuing the bilateral option more actively but he does not see this as undermining the multilateral approach. "For the foreseeable future, we in Europe, you in the US and, increasingly, they in Asia, are going to pursue a mix of multilateral and bilateral trade agreements. I think this is healthy" (Lamy, 2003). The Achilles heel of any attempt by the EU to wield the regionalism stick is, again, its reluctance to grant sufficient agricultural concessions to its negotiating partners to make such deals attractive. Regionalism will not prove an attractive option to the major developing countries as an alternative to reviving multilateral negotiations. It would seem strangely ironic if these countries were individually to accept in bilateral deals what they have collectively rejected in the multilateral process.

\section{Significance of the peace clause}

A more attractive option for developing countries to pursue their objectives would be to use their existing rights under the WTO Agreements to attack developed country agricultural subsidies. Currently, Article 13 of the AoA, known as the 'Peace Clause' puts some restraints on the exercise of the normal rights which WTO Members have to react against the unfair effects of other countries' subsidies. Under Articles XVI and VI of GATT 1994 and the Agreement on Subsidies and Countervailing Measures, two types of remedies are available against subsidies:

- imposition of countervailing duties, if there is material injury or the threat of material injury to domestic production resulting from these subsidies;

- making use of the dispute settlement mechanism against the subsidising Member if, as a result of the subsidy, there is either serious prejudice to the domestic industry, material injury or threat of injury to the domestic industry, 
or nullification or impairment of benefits accruing to that Member even where the behaviour of the subsidising Member does not infringe a GATT provision (these latter are called non-violation complaints).

The Peace Clause limits the right of countries to impose countervailing duties or initiate dispute settlement proceedings. In the case of domestic subsidies, a distinction is drawn between Green Box and trade-distorting subsidies. Green Box subsidies are exempted from countervailing duty action and the dispute settlement process. In the case of trade-distorting subsidies, due restraint should be shown in initiating countervailing duty investigations, the dispute settlement process cannot be activated provided that the measures do not grant support to a commodity in excess of the level during the 1992 marketing year and the measures are also exempted from nonviolation complaints. Conforming export subsidies have the protection that due restraint should be shown in initiating countervailing duty investigations, and action through the dispute settlement process cannot be taken.

These provisions are valid for the "implementation period" which is defined in Article 1(f) of the AoA as the nine-year period commencing in 1995. Thus the Peace Clause protections are set to expire on 1 January $2004 .{ }^{9}$ The implications of this expiry is that countries aggrieved by, for example, the EU's use of export subsidies or the US use of domestic subsidies could challenge these in the dispute mechanism process. Developing countries and other agricultural exporters, if frustrated by the apparently slow progress in liberalising farm trade through negotiation, will be tempted to seek more rapid progress towards this objective through the dispute resolution mechanism. For example, Australia, Brazil and Thailand have already initiated cases against the EU and US on cotton and sugar. They may indeed be successful in this objective, although there is a serious risk that the ensuing series of trade disputes would lead to a further poisoning of the world trade climate. ${ }^{10}$

Countries, such as the EU, which have benefited from the Peace Clause will insist that its renewal is a precondition for continuing negotiations. The EU has warned that exporting countries face a mutually exclusive choice between achieving their objectives either through litigation or through multilateral negotiation. However, it appears to have no real leverage to secure its continuation, as it is hard to see what they might offer to developing countries, in particular, who have relatively few subsidies and thus have little interest in allowing an extension of the Clause. It hardly seems credible that the EU, having invested so much in the Doha Development Round, would be willing to walk away from further negotiations if it did not get its way on this issue, particularly as it would take at least two years before the consequences of any successful complaint against it would be felt. ${ }^{11}$ However, even if there is no formal waiver or moratorium, there could be a tacit agreement to show restraint if there was clear evidence that the developed countries were prepared to

\footnotetext{
${ }^{9}$ Some have tried to interpret the "beginning of the implementation period" as meaning the time when their implementation commitments began, which in the case of the EU would be 1 July rather than 1 January.

${ }^{10}$ For a view on the prospects for bringing a successful challenge to agricultural subsidies under the GATT 1994 and the Agreement on Agriculture following the expiry of the Peace Clause, see Steinberg/ Josling, 2003.

${ }^{11}$ This includes the time for the consultations, panel hearing and report, appeal to the Appellate Body and the time allowed to a country to bring its laws and regulations into compliance.
} 
move closer to developing country demands on agricultural issues (Bridges Vol. 7, No. 31, 25 September 2003).

\section{Moving towards Geneva}

The meeting of the WTO Council in Geneva on 15 December 2003 was mandated to take stock of the fallout from the failure of the Cancún meeting, and 'to take the action necessary at that stage to enable us to move towards a successful and timely conclusion of the negotiations' (WTO, 2003d). A number of countries, such as the APEC countries (including the US), and those of the G20 meeting in Buenos Aires in early October 2003, had indicated that they were willing to resume negotiations on the basis of the Derbez text (even though the latter roundly rejected this text at the Cancún meeting) (Financial Times 22 October 2003). ${ }^{12}$ The EU reacted more cautiously, with Lamy expressing amazement at "the amazing race over the last week to endorse the text produced in Cancún on 14 September" (Lamy, 2003). Noting that many WTO members had attacked the document in Cancún, he said: "I am left to wonder, rather, what magic dust has been shaken over a text so roundly rejected in September, to find it so roundly endorsed in October" (Lamy, 2003). However, he also stated that he thought the Cancún text was a "pretty good effort even if it caused us some real grief on agriculture" (Lamy, 2003). Subsequently, it has been reported that the EU and the US are prepared to use the Derbez text as the basis for further discussions (Bridges Vol. 7, No. 34, 15 October 2003).

While the outline of a potential deal on agriculture can be discerned, the way forward for the resumption of the Doha Round negotiations remains unclear. Removal of the roadblock caused by the Singapore issues (the EU, at least, has now indicated that it is prepared to adopt a more flexible approach on these issues, see Commission, 2003) would certainly facilitate progress in the agricultural negotiations. More broadly, the frustrations of the developing countries that their concerns, on implementation and on improving special and differential treatment provisions, have not been addressed in the period since Doha despite the promises on that occasion, will also need to be tackled (Chetaille/Tavernier, 2003). The cotton issue remains important in this regard.

But there remains a sense that success might be elusive. Following the failure of the Seattle WTO Ministerial Council to launch a comprehensive round of trade negotiations, success at Doha in 2001 was achieved in part because of its proximity to the terrible events of 11 September that year and the desire of countries to demonstrate solidarity at that time. Business pressures in the major countries, and the pressures of exporting interests in particular, have appeared much more ambivalent about the importance of successfully concluding a new round than was the case in the Uruguay Round. With a more divided international climate in 2003 over policy towards Iraq, the necessary momentum behind the talks has been slow to build up. The US commitment to a successful round, which had never seemed wholehearted, has cooled markedly as the US has been put on the defensive over the 2002 Farm Bill and cotton subsidies. The escalating number of US-EU trade disputes (steel, FSC, hormones, GMOs, the US Bio-Terrorism and Buy American Acts, the new EU chemicals policy), the US Presidential election in 2004 and the replacement of

\footnotetext{
${ }^{12}$ There is speculation that the apparent softening in the position of the G20 group may reflect the haemorrhaging of members since the Cancún meeting. Only 12 countries signed the political declaration at the end of the Buenos Aires meeting, see Bridges Vol. 7, No. 34, 15 October 2003.
} 
Paschal Lamy as the chief negotiator on the EU side when the new Commission takes office next year also add to the general uncertainty. Progress on agriculture may depend on whether an improvement in the overall negotiating climate can be achieved, but there is no doubt that progress on agriculture would also help greatly to bring about that needed improvement. Negotiations on agriculture are set to resume in March 2004. Although some Members have expressed the view that sufficient progress may be made to permit at least an informal ministerial by year end, it seems more likely that meaningful negotiations will not resume until the next Ministerial meeting planned for Hong Kong in 2005. Such a delay, while regrettable, would draw parallels with the Uruguay Round experience. If a good agreement on agriculture is attainable, it is worth waiting for.

\section{References}

CAFOD (2003), The Cancun WTO Ministerial Meeting, September 2003: What happened? What does it mean for development?, CAFOD Policy Paper, UK , available on www.cafod.org.

Chetaille, A./Tavernier, K. (2003), Failure of the Fifth WTO Ministerial Conference in Cancun: a Looming Crisis in the Multilateral Trade System?, Agritrade and Solgral, September, available at http://agritrade.cta.int/.

Commission of the European Communities (2003), Reviving the DDA Negotiations the EU Perspective, Communication from the Commission to the Council, to the European Parliament and to the Economic and Social Committee, Brussels, 26 November 2003.

Danish Research Institute of Food Economics (2003), Note on the Harbinson Draft on Modalities in the WTO Agriculture Negotiations, Copenhagen 2003.

International Centre for Trade and Sustainable Development (ICTSD) (2003), Agriculture Negotiations at the WTO: Post-Cancún Outlook Report, November 2003, available at www.ictsd.org.

Lamy, P. (2003), Trade Crisis?, Speech delivered to the European Institute, Washington, 4 November 2003 available at http://europa.eu.int/comm/commissioners/lamy/speeches_articles/spla198_en.htm.

Steinberg, R./Josling, T. (2003), When the Peace Ends: the Vulnerability of EC and US Agricultural Subsidies to WTO Legal Challenge, Journal of International Economic Law 6(2): 369-417.

(an abbreviated version of this article appeared in Bridges No. 7, Issue 8, November 2003, available at www.ictsd.org)

WTO (2001), Declaration of the Fourth WTO Ministerial Conference (the Doha Declaration), WT/MIN(01)/DEC/W/1, available at www.wto.org.

WTO (2003a), Draft Cancún Ministerial text submitted by General Council chairperson Carlos Pérez del Castillo and Director-General Supachai Panitchpakdi 31 August 2003, JOB(03)/150/Rev.1. 
WTO (2003b), Consolidated African Union/ACP/LDC Position On Agriculture: Communication from Mauritius, WT/MIN(03)/W/17.

WTO (2003c) Draft Cancún Ministerial text submitted by Ministerial Council chairperson Luis Derbez 13 September 2003, JOB(03)/150/Rev.2.

WTO (2003d), Ministerial Statement following the Cancun Ministerial Council, available at

http://www.wto.org/english/thewto_e/minist_e/min03_e/min03_14sept_e.htm\#statem ent.

WTO (2004), WTO Agriculture Negotiations: The issues, and where we are now, Updated 1 March 2004, available at www.wto.org. 